\title{
TANÍTÓKÉPZÉS KETTŐS KÖTÉSBEN
}

\author{
HUNYADY GYÖRGYNÉ \\ az Eötvös Loránd Tudományegyetem Tanító- és Óvóképző Karának \\ föiskolai tanára \\ hunyady.gyorgyne@tofk.elte.hu
}

A tanítóképzésnek kezdeteitől fogva alapvető és még a pedagógusképzésen belül is megkülönböztető vonása a közvetlen kapcsolat a közoktatással, s ez érdemben így maradt az elmúlt ötven évben is, amelynek során a tanítóképzés a felsőoktatás integráns részévé vált.

\section{Tanítóképzés a közoktatás szolgálatában}

A tanítók közoktatási munkájához való kötődés elementáris formája volt az ún. előkép-teória (Bollók, 1990), mely szerint a tanítóképző intézeti oktatásnak a népiskolai tanítás előképének kell lennie. Az 1869-es tanterv ezen vezérelve szabta meg a tanítóképzés egész struktúráját és módszertanát. Ennek az elvnek a mechanikus érvényesítése az idők folyamán természetesen fellazult, $\mathrm{s}$ ma már nyilvánvaló, hogy a tanító tudásának mind terjedelmében, mind szakmai mélységében lényegesen meg kell haladnia az iskolai tanulókkal együtt feldolgozandó tananyagot, de a tanítóképzést mindmáig áthatja a közoktatási célszerüség szempontja és logikája.

Az előkép-teória azonban sokáig vissza-visszatért a képzésben: Nótin Lajos egy 1978-as tanulmányában arról ír, hogy „a felsőfokú tanítóképzés kezdő éveiben... a szakmódszertan törzsanyaga a mindenkor érvényben volt általános iskolai tananyag feldolgozásának technológiája volt. Nem több, gyakorta kevesebb, mint amit a kézikönyvek tartalmaztak." (Nótin, 1978, 133. o.) Vagy: 1984-ben egy szakmai tanácskozáson a magyar nyelv és irodalom számára nagyobb óraszámot igényeltek a tanítóképzésben. A fó érv az volt, hogy a közoktatásban az alsó tagozatban az anyanyelvi tárgyak óraszámának aránya magasabb, mint a képzésben (Laczkó, 1984).

A közoktatási célszerüség azonban korábban sem azt jelentette, hogy a tanítóképzés egy statikus rendszert pusztán kiszolgál. Amikor a tanítóképzés még a közoktatás része volt, képviselői a népiskola fejlesztésében nagy súllyal, tekintéllyel és hatékonysággal vettek részt. És itt nemcsak Gyertyánffy István (Gyertyánffy - Kiss, 1876; Magyarfalvy, 1968) vagy Nagy László (Nagy, 1908; 1919; 1921) személyes teljesítményére és intellektuális kisugárzására kell gondolnunk, hanem a tankönyvírók és segédeszköz-készítők népesebb csoportjára is. Az elmúlt ötven évben a 
közoktatásnak ez a szegmense sokat változott, igényeinek kielégítésében, majd felgyorsult dinamikájában a tanítóképzőknek aktív szerep jutott. Az első évtizedekben a közoktatási igények olyan megrendelések formájában jelentkeztek, hogy a leendő tanítókat milyen ismerettöbblettel kell ellátni, milyen feladat-többletre kell felkészíteni (pl. mozgalmi munka, technikai képzés, korrekciós nevelés stb. Vö. Az általános iskolai és óvodai pedagógusképzés tantervei, 1976-77, 23. o.) A '80-as évek elejétól a közoktatás egyre változatosabb képet mutatott, választható tankönyvek sora jelent meg, kísérleti programok, majd alternatív pedagógiák nyertek teret. A tanítóképzésnek erre is meg kellett találnia a maga válaszát. Ugyanakkor a közoktatási problémákkal és lehetőségekkel szembesülve a szakma egy sor területen saját kezdeményezéssel élt, hogy hozzájáruljon a közoktatás megújulásához.

Az utóbbival kezdve hadd említsek néhány példát: a tanítóképzők korán és kezdeményező módon érzékelték a kisiskolások társadalmi és pszichológiai heterogenitását, a gyerekek eltérő nevelési szükségleteit, és így váltak a differenciáló-fejlesztő pedagógia mühelyeivé (vö. pl. Glauber - Tihanyiné, 2006). Ez a problematika témakörök, majd tantárgy formájában megjelent az alapképzésben (vö. A tanitóképzö föiskolák tanterve, 1980-81), s a képzők hamarosan megszervezték a tanítók (és óvodapedagógusok) továbbképzését is ezen a területen.(A Tanitó, illetve Óvodapedagógus fejlesztö pedagógiai szakon c. szakirányú továbbképzési szakok akkreditált képesitési követelményei, 1996). Ez az irány is támogatta azt a törekvést, hogy a személyiségfejlesztés legyen önálló és kitüntetett területe a tanítóképzésnek, aminek jegyében a képzőkben honosodott meg elsőként az önismereti csoportoknak a pedagógusképzésbe beépíthető és beépítendő módszertana. (Vö. A tanitóképzö föiskolák tanterve, 1980-81)

Az átfogó szemléleti változásokon túl számos szakterületen születtek a tanítóképzőkben fontos innovációk, melyeknek egy része erős és tartós közoktatási hatással járt, más része - minden értéke ellenére - megtorpant és elakadt. Valamennyien számon tartjuk pl. a matematika tanítás módszertanának megújítását, amelyben jelentős részt vállaltak a tanítóképzők osztozva e vállalkozás sikereiben és kudarcaiban (Nótin, 1978). Koncepcionális változást szorgalmaztak a tanítóképzők a vizuális nevelés területén, ezt érvényre is juttatták saját felsőoktatási gyakorlatukban, a közoktatásra kisugárzó - ha nem is átütő - hatással (Leitner, 1985; Bálványos, 1995). A természetismeret tanításának módszertanában gyökeres változásokat ígért a tanulói tevékenységre építő képességfejlesztés szándéka, a diszciplinárisan megalapozott tudásanyag integratív jellege (Véghelyi, 1995). Ez a szakmai innováció jó időben és jó helyen jelentkezett a tanítóképzőkben, ezért is sajnálatos, hogy mindmáig nem vált széles körü gyakorlattá az alsó tagozatos oktatásban. A hazai kulturális viszonyok között, a nyelvismeret hiányával küszködő társadalmunkban fontos fejlemény, hogy a képzőhelyek jóvoltából létrejött a tanítóknak egy idegen nyelv oktatására felkészült csoportja. 
A szaktárgyi kezdeményezéseknek ez a futó áttekintése el is vezet bennünket a hazai tanítóképzés fontos fejleményéhez, a sajátos elmélyedést nyújtó szakkollégiumok, majd a müveltségterületek kiépüléséhez (Szövényi, 1980). A szakkollégiumi rendszer eredeti céljain túl egy későbbi fázisban konstruktív segítséget tudott nyújtani a közoktatásban jelentkező pedagógushiány enyhítésére, mivel a környezetismeret, az ének-zene, a testnevelés, a rajz- és technikatanítás területén jobban felkészült tanítók az 5. osztályban is jogosultak voltak tanítani. Ezen túllépett a képzés egész rendszerére kiterjedő múveltségterületi képzés, amely minden leendő tanító számára lehetővé tette, sőt elöírta egy-egy szélesebb szakterületen való elmélyülést, ily módon egészítette ki tudásukat és adott mindenki számára egy, a 12. éves korig előretekintő szakmai perspektívát (Bollók - Hunyady,1995). A közoktatás szakaszolásának, a kezdőszakasz megnyújtásának vitái hosszabb ideje zajlanak és jelenleg egy felemás megoldásig jutottak el, ami is a nem szakrendszerü oktatás keretében ad teret a tanítók munkájának az 5-6. osztályban (A közoktatásról szóló 1993. évi LXXIX. törvény elöírásait módosító 2003. évi LXI. törvény). Figyelemmel a közoktatás fejlödésének nemzetközi trendjére, többek között a sok vonatkozásban emlegetett finn példára, azt bizonyos megelégedettséggel állapíthatjuk meg, hogy a magyar tanítóképzés az 1-6. osztályos kezdőszakaszra legalább egy területen felkészíti hallgatóit, s erre a felkészültségre szükség lehet nemcsak az európai összerendeződés, hanem a kistelepülések iskoláinak fenntartása érdekében is (Bollók - Hunyady, 2003).

Mint elöljáróban már említettem, a közoktatásban a '80-as évek elejétől végbemenő differenciálódás, amelyet azután felerősített a tudatos, esetenként túlhajtott decentralizáció, átfogó szemléletváltásra késztette a tanítóképzést. Fel kellett készülnie és fel kellett készítenie hallgatóit arra, hogy az iskolai munkának nem egyetlen kijelölt útja van, hanem sokféle tanterve, programja, választható taneszköze. Lehetetlen ezek használatára részleteiben azonos mértékben felkészülni, viszont szert kell tenni a képzés során olyan alapokra, amelyek a legkülönbözőbb irányokban biztonságos kiindulópontot jelentenek és kamatoztathatók. Ez az alapozás képessé tesz kritikára és kreativitásra egyaránt. Nyilvánvaló, hogy a legnehezebb stratégiai feladatok egyike megtalálni a különböző alternatívák közös nevezőjét és közös támaszát. Óhatatlan, hogy ennek keresése ne váltson ki többoldalú bírálatot: egyfelöl azt a vádat, hogy a tanítóképzést avitt pedagógiai konzervativizmus jellemzi, másfelől azt a vádat, hogy elbizonytalanító nyitottságával nem készíti fel hallgatóit megfelelően az iskola konkrét gyakorlatára. Az ilyen ellenvetéseket szinte lehetetlen elkerülni, a választ rájuk a végzett tanítók közoktatási helytállása adhatja és adja meg (Csík, 1985; Vekerdy, 1989).

Az eddigiekben azt hangsúlyoztam, hogy a tanítóképzés egyik éltető eleme a közvetlen kölcsönös kapcsolat a közoktatással, és hogy ezt, belépése a felsőoktatás intézményrendszerébe, nem halványította el. Joggal adódik azonban az a másik kérdés, hogy a hosszabb ideje készülődö, majd ötven évvel ezelőtt realizálódó 
szervezeti változás, a felsőfokú tanítóképzés megszületése mennyiben jelentett elöre vivő erőt, hogyan járult hozzá a tanítóképzők szakmai arculatának alakulásához.

\section{Beilleszkedés a felsőoktatás rendszerébe}

Amint ez a történeti visszatekintésekből is egyértelműen kitünik, több alapos indoka volt annak, hogy a közoktatás kereteiben népszerü és színvonalas tanítóképzés egy szinttel feljebb lépjen az oktatás rendszerében. A tanító iskolai feladatainak szakmai összetettsége és az ehhez szükséges háttértudás növekedett, valamint ennek a hivatásnak nemzeti szempontból is megkérdőjelezhetetlen társadalmi jelentősége és felelőssége megkívánta a több időt és nagyobb anyagi ráfordítást, a specializált intézményrendszer kiépítését. Visszatekintve mondhatjuk, hogy a tanítóképzés kiemelkedése a közoktatásból, amely régi ambíció volt és úttörő fejlemény lett, beilleszkedett az értelmiségképzés általános hazai fejlődésmenetébe. Továbbá sokunk közös tapasztalata világszerte, hogy a szakmai személyiség kiérlelödése időben kitolódott, ami a pedagógusképzés területén is indokolja, hogy az egész személyiségével dolgozó szakember ne 18 éves korában lépjen be teljes felelősséggel az iskola gyakorlatába.

Az országban sok helyütt folyt középfokú tanítóképzés, és ez a tény is hozzájárult ahhoz, hogy az átalakuláskor 10 felsőfokú intézményben folytatódott a képzés. A következő évtizedekben a képzőhelyek száma lassan, de folyamatosan bővült. Részben a hagyományok elejtett szálának felvétele miatt, részben a '70-es években mutatkozó szinte drámai mértékü tanítóhiány miatt, s az is bizonyítható, hogy a politikai erők a regionális felsőoktatás-építés viszonylag könnyü és kézenfekvő útjának tekintették újabb óvó- és tanítóképzőhelyek létesítését. Az ezredfordulóra ez már kétségtelenül a túltermelés és a szétforgácsolódás veszélyét hordozta, mely utóbbit részlegesen ellensúlyozta a szakma egészséges önvédelme: a tantervi egyeztetés szoros rendje és folyamatos fenntartása. A főhatóság intenciója mellett ebben mindmáig ott munkál a képző intézmények szándéka, hogy összehangolják a tanítóképzés tervezését, a tantervek bevezetését és együttesen hasznosítsák ennek tapasztalatait, még a minőségbiztosításra vonatkozó kampányokat megelőzően értékeljék tapasztalataikat és visszacsatolják a képzés gyakorlatába. Az összehangolásnak fontos periódusa és formája volt az Országos Tantervfejlesztő Bizottság létrejötte 1987-ben. Munkájában átmeneti hullámvölgy következett be az intézményi integráció fázisában, de napjainkban újra erősödni látszik a szakmai együttmüködésnek ez az igénye (Bollók - Hunyady, 2003).

A képzés volumene és a képző intézmények száma bizonyos értelemben befolyásolta ennek a területnek a beilleszkedését a felsőoktatásba. Ha őszintén beszélünk erről, mondhatjuk, hogy ezek a nagy számok hozzájárultak ahhoz a most már rögzült tendenciához, hogy a különösen intenzív gyakorlati tevékenységet is igénylö óvó- és tanítóképzés normatívája megindokolhatatlanul elmaradt mondjuk a viszony- 
lag közelfekvő gyógypedagógus-képzésétől, és ebben a pedagógusképzés beszükítésének idején méltányos változást nem is remélhetünk. (A gyógypedagógus BA szak normatívája 585 eFt, a tanító alapszaké 220 eFt. 2008-as Kormányrendelet.)

A szervezeti kiépülés időszakában válaszút állt a tanítóképzők előtt: a felsőoktatási követelmények enyhítését, lazítását szorgalmazzák-e sajátos feladataikra és szerényebb feltételeikre hivatkozva vagy pedig azt tüzzék ki célul, hogy megfelelö moratóriummal, de elérik a tudományos munkával és kvalifikációval szembeni általános követelmények szintjét. Ez nyilván nem volt egy könnyü döntés, de a több ciklusú képzés bevezetése és a tanítóképzőkben végbemenő generációváltás együttesen végül is az utóbbi megoldást támogatta.

1959-et követően másfél évtizedet vett igénybe a felsőfokú intézetek főiskolákká válása. Ez a kiküzdött eredmény közelebb hozta a tanítóképzőket a tanárképző főiskolákhoz, ami már addig is, a későbbiekben is egyaránt jelentett fontos húzóerőt és veszélyforrást. Mind a hallgatók, mind az oktatók számára - úgy tủnhetett a szakmai előrehaladás és elismerés kínálkozó következő lépcsőfoka az általános iskolai tanárképzésbe való átlépés. Ambiciózusabb hallgatóink úgy gondolták, hogy úgy lépnek elöre, ha majd tanár lesz belőlük és ebből a szempontból is ígéretet láttak a szakkollégiumi rendszerben. Az oktatók súlyt fektettek a diszciplináris tagolásra és elmélyülésre, ezzel a tanítóképzést közelítették a tanárképző főiskolák struktúrájához, nemegyszer saját szakmai karrierjüket a tanárképző föiskolákon látták és biztosították. Nem kell hosszan magyaráznom, hogy ennek a kapcsolódásnak volt logikus alapja és előrevivő szerepe, de veszélye is, amennyiben a tanítóképzés gyakorlati, módszertani értékeit rontotta, és némileg aláásta a tanítói identitást. Vagyis azt a tudatot és elkötelezettséget, hogy a kisiskolások különösen érzékeny és a szocializációban kulcsfontosságú iskolázásában betöltött szerep önmagában értékes, ezért a tanítói pályán a kisiskolás kor pedagógiájában lehet és szükséges előrelépni.

A bolognai reform a tanítóképzés helyét és szerepét markánsabbá tette és megszilárdította. Az új szisztémában - hosszú elvi viták után - egyértelműen szétvált a pedagógusképzés két útja: az alapképzésben zajló óvó- és tanítóképzés, illetve a diszciplináris alapozásra építő tanári mesterszak. A reformot megelőzően megszületett, kiépült és bevált a tartalmilag megújított négyéves tanítóképzés, amely arra törekedett, hogy visszaállítsa a tanítóképzés markánsan gyakorlatorientált pedagógiai jellegét, $\mathrm{s}$ ennek jegyében növelje meg a tantárgy-pedagógiai felkészítés jelentőségét is (Hunyady - Magyarfalvy,1990; Hunyady, 2000). A reform úgy fogadta be a tanítóképzést a kétciklusú rendszerbe, hogy ezekben a szakmai vívmányokban nem okozott kárt, hanem - valóban rendkívüli kivételként - négy évet biztosított $\mathrm{e}$ képzési feladatra (H. Nagy, 2003; 2005-ös Korm.rendelet). (Zárójelben jegyzem meg, hogy a tanítóképzés rendkívüli abban a tekintetben is, hogy sok más alapképzéstől eltérően valóban felkészít egy hivatás gyakorlására, konkrét szakképzettséget ad, nem pusztán kissé bizonytalan kimenetelủ alapvetést egy szakterületen.) A tanárképzés esetében a közoktatási feladat nélkülözhetetlenné teszi a diszciplináris 
alapozást, Ugyanakkor a mester szak elvben szintén pedagógiai karakterü, célirányosan a közoktatási gyakorlat felé fordul, sőt - szintén rendkívüli kivételként egy ötödik, kifejezetten terepgyakorlati félévvel válik teljessé. (Így valósult meg a bolognai rendszerben a sokszor igényelt egységes tanárképzés a bővebb szakmai és módszertani kereteket biztosító magasabb, egyetemi szinten.) A bolognai reformok bevezetésének viharos vitáiban természetesen felmerült az a kérdés is, hogy a tanítóképzés maga ne emelkedjen-e mesterszintre vagy ne rendelkezzen-e alap és mesterszintü kimenettel egyaránt (Kelemen, 2000; Zsolnai, 2003). A magam részéröl úgy gondoltam és úgy gondolom, hogy a szerkezeti átalakítás hevében kár lett volna feladni a négyéves tanítóképzés eredményeit és feltételeit, vagy a tanítók két rangosztályát meghonosítani az iskolában. Szakmailag nehezen lett volna indokolható négy évnél hosszabb képzési időt igényelni. Azt viszont - reményem szerint a tanítóképzés több elkötelezett hívével együtt - úgy vélem, hogy a kialakult kétlépcsős rendszer a tanítóképzés zsákutcás jellegét sikerrel és elörevivő módon szünteti meg azzal, hogy a végzettek útja megnyílt a neveléstudományi mesterképzésben (Bollók, 2003; Bollók - Hunyady, 2003; Ladányi, 2003). Ez a szak, s különösen a kisiskolás kor pedagógiája szakirány ad tudományos perspektívát a gyakorlatorientált tanítóknak. Ugyanakkor a neveléstudomány müvelése és fejlesztése szempontjából is kulcsfontosságú ennek az érzékeny életkornak és nagyhatású iskoláztatási szakasznak az elmélyült tanulmányozása.

A magyar felsőoktatás dinamikus változásai során, nemcsak a tanítóképzés tartalma és szerkezete változott és fejlődött, hanem intézményi beágyazottsága is. Az integráció talán a legnagyobb hatással az óvó- és tanítóképzők státuszára volt. Ezek rendre mind nagyobb intézmények részeivé váltak, nemegyszer egyetemekbe illeszkedtek, s ilyen értelemben elvesztették szervezeti önállóságukat. Már ezt megelőzően is, a túlélés érdekében és a szellemi expanzió jegyében a tanítóképzők reagálva a helyi, regionális igényekre is - gazdagították és differenciálták képzési profiljukat. Ez a folyamat a szervezeti integrációval csak erősödött. Ennek következményeként ma már ritka - mondhatnánk egyedi - hogy egy-egy részintézmény kizárólag vagy domináns módon az óvó- és tanítóképzéssel foglalkozik. A végbemenő felsőoktatási integráció azzal járt, hogy a tanítóképzés egy a szakok közül, és ma az a tennivaló, hogy ennek a szaknak a legértékesebb hagyományait - így a közoktatással való közvetlen kapcsolatát - megőrizzük, ugyanakkor kiaknázzuk mindazokat az előnyöket, amelyek a tágabb intézmények szervezeti keretében és színesebb szellemi atmoszférájában adódnak.

Csak remélni tudom, hogy a képzők új generációja, amely már ezekkel a viszonyokkal és kilátásokkal ismerkedik meg, kellő felkészültséggel és nélkülözhetetlen elkötelezettséggel fogja folytatni a most ünnepelt 50 év pedagógusképző munkáját. 


\section{Irodalom}

289/2005 (XII.22.) Korm. rendelet a felsőoktatási alap- és mesterképzésről, valamint a szakindítás eljárási rendjéről.

http://net.jogtar.hu/jr/gen/getdoc.cgi?docid=a0500289.kor

50/2008.(III.14.) Korm.rendelet a felsőoktatási intézmények képzési, tudományos célú és fenntartói normatíva alapján történő finanszírozásáról. http://net.jogtar.hu/jr/gen/getdoc.cgi?docid=a0800050.kor

A közoktatásról szóló 1993. évi LXXIX törvény elöírásait módosító 2003. évi LXI. Törvény.

A Tanitó, illetve Óvodapedagógus, fejlesztő szakirányú szakon c. szakirányú továbbképzési szakok akkreditált képesitési követelményei, (1996), BTF, Budapest.

A tanitóképzö föiskolák tanterve. Az 1980-81-es tanévtől. Oktatási Minisztérium Kiadványa, Budapest.

Az általános iskolai és az óvodai pedagógusképzés tantervei. Az 1976-77. tanévtől. Oktatási Minisztérium Tudományegyetemi és Tanárképző Főiskolai Főosztály Pedagógusképző Osztály, Budapest.

Bálványos Huba és mtsai. (1995): A vizuális nevelés müveltségterület programja. In: Bollókné Panyik Ilona - Hunyady Györgyné (szerk.): A négyéves „,tanitó ” szak programja. Tanító- és Óvóképző Főiskolák Főigazgatói Kollégiuma, Budapest.

Bollókné Panyik Ilona (1990): A magyar tanítóképzés tantervtörténeti előzményei és hasznosítási lehetőségeik a négyéves tanítóképzés tervezésében. In: A tartalmilag megújitott négyéves tanitóképzés (Helyzetfeltáró előtanulmányok). A felsőoktatás fejlesztését szolgáló kutatások. Budapest, 13-47.

Bollókné Panyik Ilona (2003): Az egységes pedagógusképzés víziója. Pedagógusképzés, 34. sz. 81-89.

Bollókné Panyik Ilona, Hunyady Györgyné (szerk., 1995): A négyéves „,tanitó” szak programja. Tanító- és Óvóképző Főiskolák Főigazgatói Kollégiuma, Budapest.

Bollókné Panyik Ilona, Hunyady Györgyné (2003): A tanítóképzés az integrált felsőoktatásban. Új Pedagógiai Szemle, 7-8. sz. 4-17.

Csík Endre, Zsolnai József (1985): A tanítóképzés kritikus pontjai és megoldásra váró problémái. In: Csík Endre (szerk.): A tanitóképzés kritikus pontjai. Vélemények, kutatási lehetöségek. Oktatáskutató Intézet, Budapest, 9-31.

Fábián Zoltán (1989): Új modellek a pedagógusképzésben. Tankönyvkiadó, Budapest.

Glauber Anna, Tihanyiné Hős Ágnes (2006): Befogadó szemlélet kialakítása az óvó- és tanítóképzésben. Pedagógusképzés, 1-2. sz. 77-87.

Gyertyánffy István - Kiss Áron (1876): A népiskola módszertana. (Dittel nyomán) Budapest.

H. Nagy Anna (2003): Pedagógusképzés a 21. században. ELTE modell I., ELTE, Budapest.

Hunyady Györgyné (2000): A négyéves „,tanító” szak programja: Bevezetés és kommentár. In: Kovátsné Németh Mária (szerk.): Óvó- és tanitóképzés az ezredfordulón. Tanító- és 
Óvóképző Főiskolák, Főiskolai Karok Kollégiuma, Óvó- és Tanítóképzők Egyesülete. Kaposvár, $89-101$.

Hunyady Görgyné, Magyarfalvy Lajos (1990): A négyéves tanítóképzés előzményeinek és koncepciójának vázlata. In: A tartalmilag megújitott négyéves tanitóképzés (Helyzetfeltáró előtanulmányok). A felsőoktatás fejlesztését szolgáló kutatások. Budapest, 3-9.

Kelemen Elemér (2000): Gondolatok a magyar tanitóképzés kettős évfordulóján. In: Kovátsné Németh Mária (szerk.): Óvó- és tanitóképzés az ezredfordulón. Tanító- és Óvóképző Főiskolák, Főiskolai Karok Kollégiuma, Óvó- és Tanítóképzők Egyesülete. Kaposvár, 7-15.

Laczkóné Riba Magdolna (1984): A tanítóképzés struktúrájának és tantervének változásai 1959-1980-ig. In: Tanitóképző Föiskolák tudományos közleményei (különkiadás). Debrecen, 47-55.

Ladányi Andor (2003): A pedagógusképzés átalakításának - fejlesztésének kérdései. Pedagógusképzés, 3-4. sz. 75-81.

Magyarfalvy Lajos (1968): Gyertyánffy István és a budai Paedagogium. Budapest.

Nagy László (1908): A gyermek érdeklödésének lélektana. Budapest.

Nagy László (1919): A magyar közoktatás reformtervezete. A Gyermek, 210-215.

Nagy László (1921): Didaktika gyermekfejlődéstani alapon. (A nyolcosztályos egységes népiskola tanterve. II. rész). Budapest.

Nótin Lajos (1978): Kísérletek és eredmények a matematikatanítás módszerében. In: A tanitóképzés évfordulói. Oktatási Minisztérium kiadványa, Budapest, 127-138.

Szövényi Zsolt (1980): A szakkollégiumi rendszerü tanítóképzés. Felsőoktatási Szemle, 4. sz. 246-250.

Véghelyi Józsefné és mtsai. (1995): A Természetismeret müveltségterület programja. In: Bollókné Panyik Ilona - Hunyady Györgyné (szerk.): A négyéves , tanitó” szak programja. Tanító- és Óvóképző Főiskolák Főigazgatói Kollégiuma, Budapest.

Vekerdy Tamás (1989): Az óvoda és az elsö iskolai évek a pszichológus szemével. Pszichológia - nevelöknek. Tankönyvkiadó, Budapest.

Zsolnai József (2003): Az egységes pedagógusképzés koncepciója és kivitelezésének lehetőségei a Veszprémi Egyetemen. Pedagógusképzés, 1-2. sz. 89-100. 